\title{
EMOTIONAL RESPONSES TO INNOVATIVE SCIENCE TEACHING METHODS: ACQUIRING EMOTIONAL DATA IN A GENERAL SCIENCE TEACHER EDUCATION CLASS
}

\author{
Jesus Sanchez-Martin*iD, Florentina Cañada-Cañada ${ }^{(\mathbb{D})}$, María Antonia Dávila-Acedo $(\mathbb{D}$ \\ Department of Science and Mathematics Education. Faculty of Education. \\ University of Extremadura (Spain) \\ *Corresponding author:jsanmar@unex.es,flori@unex.es,mdavilaacedo@unex.es
}

Received February 2018

Accepted May 2018

\section{Abstract}

The current work tries to inquiry how different teaching methods affect on the student's emotional performance. The traditional questionnaire for data collection has been replaced by in-situ, on-lineassisted, survey. This instrument was continoulsy applied over the course of 17 General Science lessons. The experiment involved 120 prospective primary education teachers. Emotions to choose: rejection, boredom, satisfaction, surprise and the teaching methods involved were pure oral presentation, oral presentation with gamification, oral presentation with audiovisual support, oriented research, and handson activities. When the teaching method was changed to gamification or hands-on activities, the prospective teachers felt dynamic emotions, whereas they generally felt satisfaction or boredom (static emotions) with a traditional pure oral presentation. The students mainly identified the teaching method as being the most influential reason for having chosen their prevalent emotion, reflected in a dramatic increase in emotional performance when they were taught with innovative methods.

Keywords - Emotions, Affective domain in science education, Teaching method, Continuous measurement.

\section{Introduction}

Moreover than the mere rational mechanisms, our behaviour is also ruled by emotional ones. This role is increasingly being considered by experts in the teaching and learning process. Although each one can without doubt acknowledge these affective aspects influence with an evident relevance on the human beings' learning process (it is hard to remember the content one has studied, but it is easy to remember how one felt when studying it), emotional domain has been systematically out education, and above all out from the specific didactics (Brígido, Borrachero, Bermejo \& Mellado, 2013). But their recent inclusion in the science education corpus (Black \& Atkin, 2005) is being continuously refined by in-class experiences such as those reported by Sánchez-Martín, Álvarez-Gragera, Dávila-Acedo and Mellado (2017a,b) and Dávila-Acedo, Cañada-Cañada, Sánchez-Martín and Mellado (2016).

As Hargreaves (1998: page 558) puts it, emotions are at the heart of education. Emotions and feelings must be included in the set of variables that the teacher has to take into account to improve the development of learning. It is recognized today that the cognitive configures the affective, and vice versa. The idea of teaching and learning as an emotional practice in which both cognitive and affective processes take part is fully accepted by researchers and educators (Brígido, Couso, Gutiérrez \& Mellado, 2013). 
Otero (2006) states that there is no human action without an emotion that substantiates it and makes it possible. Emotion is therefore central to decision making (Damasio, 1996). Students find decision making especially important at the end of their compulsory education when they have to decide on their future studies (Lavonen, Gedrovics, Byman, Meisalo, Juuti \& Uitto, 2008), hence the relevance of adequate management of emotions in encouraging or discouraging their future vocations. Primary teachers' own ideas and emotions towards science and science education are projected onto their students (Borrachero, Brígido, Mellado Costillo \& Mellado, 2014), so that it is crucial to promote positive emotions at every educational level, including university. Numerous studies have found that the attitudinal and emotional factors involved in learning science become increasingly negative with age, especially so during secondary education (Marbá-Tallada \& Márquez, 2010; Vázquez \& Manassero, 2011).

Consequently, it could be said that the decline of vocational careers in science and technology in many countries is related to the adverse emotional context surrounding the learning of science and technology at school (Vázquez \& Manassero, 2007). The decrease in engineering and science vocations is a confirmed fact that will have economic implications for the future. Rocard, Csermely, Jorde, Lenzen, Walberg-Henriksson and Hemmo (2007) warned that European society, with its knowledge-based economy, could be endangered if the number of students interested in these topics continues to decrease. Also, the proportion of citizens who are illiterate in scientific and socio-scientific issues has increased alarmingly. A recent survey in Spain (FECYT, 2014) found that almost a quarter of the country's population has zero interest in scientific issues, and one of the main reasons for this lack of interest is their misunderstanding of what science deals with. In the same sense, almost a half of that sample thought that their level of scientific education was low or very low. Some of the responsibility for this situation must be laid on the schools, with some of these ideas being caused by the teachers and the methods they use to teach science.

The importance of adequate emotional management in the context of education has been known for a long time. Towards the end of the last century for example, Pintrich, Marx and Boyle (1993) argued for the importance of motivation and the emotions as being determinants in learning. As noted by Vázquez and Manassero (2007), positive emotions favour learning, whereas negative emotions severely limit the ability to learn. Conceptual change is therefore both cognitive and affective (Thagard, 2009), and teachers who ignore the affective aspects of learning may limit their students' conceptual change (Duit, Treagust \& Widodo, 2008).

There are a variety of taxonomies for the domains of affect, emotions, and feelings (Mellado, Borrachero, Brígido, Melo, Dávila, Cañada et al., 2014). Dos Santos and Mortimer (2003) considered the affective domain to be more general, and to subsume emotions, feelings, and moods. Many authors agree that while emotions are the organism's automatic responses to external stimuli, feelings are more permanent. In the present study, we shall primarily be referring to emotions, although we shall sometimes refer generically to the affective dimension. Of the many definitions of emotions, the one we adopt is that put forward by Bisquerra (2001):

\section{Emotions are reactions to the information we receive in our relationships with the environment. The intensity of the reaction depends on the subjective assessment made of how this information will affect our well-being. These subjective assessments will involve prior knowledge, beliefs, personal objectives, perception of a challenging environment, etc. An emotion depends on what is important to us.}

Despite this general definition, there are different, culturally dependent, conceptions of emotions, and these can even change over time within the same culture. The existence of various alternative classifications may therefore be justifiable. One of the most widely used classifications distinguishes between basic or primary emotions and complex or secondary emotions (Francisco, Gervás \& Hervás, 2005). Damasio (2010) classifies emotions as primary or basic, background or social. Casacuberta (2000) makes a more finely categorized classification in which basic emotions can be classified into six groups: surprise, happiness, fear, rejection, wrath, and sadness. But the classification closest to the nature of the present study is based on one which distinguishes between positive, negative, and neutral emotions 
(Bisquerra, 2009; Brígido, Couso et al., 2013; Fernández-Abascal, Martín \& Domínguez, 2001), as will be further developed below.

The importance of emotions in the motivation and in the academic performance was already pointed out (Manassero, 2013) Obviously, every student feels differently when they perceive success or failure. Positive emotions stimulate academic effort and self-confidence, while no appreciation of success would lead to a fall in academic performance (Weiner, 1986). It is worth noting that there are no totally negative emotions since anxiety could be a motivational force, although it could also block students and even adults (Goleman, 1996). Hence, a student may be blocked in the face of such emotional situations as frustration, wrath, or impotency whether in or out of class. On the other hand, favouring positive emotional states means favouring learning, and vice versa (Vázquez \& Manassero, 2007).

The relevance of emotions as activators of the learning process has rarely been considered, and there is almost no academic literature on the topic in the field of university education (Jeong, González-Gómez \& Cañada-Cañada, 2016). Previous research has indicated the need to analyse the emotions by distinguishing the different subjects of science and technology (Vázquez \& Manassero, 2007). Other studies have shown that secondary education students have positive attitudes and emotions towards Biology and Geology and negative ones towards Physics and Chemistry (Borrachero, Brígido, Gómez, Bermejo \& Mellado, 2011; Brígido, Borrachero et al., 2013; Marbá-Tallada \& Márquez, 2010). Some studies have pointed to the need for experiences in the learning process during the early years of school. An example is that carried out by Mooney and Laubach (2002) with students in the last year of primary education which involved a fullimmersion experience that linked inquiry-based learning and positive emotions.

Wu and Huang (2007) investigated the cognitive, emotional, and behavioural engagement of first-year upper secondary students in teacher-centred and student-centred technology-enhanced classes. The results showed the students in the student-centred class to present significantly greater emotional engagement and to interact more in discussion groups, although this had no impact on their actual achievement in learning.

Also notable is the fact that active assumption of scientific and technological issues at an emotional level is absolutely essential for the integration of this content. Consequently, science that is learned under conditions of negative feelings will be of little use to the learners, whether they are schoolchildren or adult students (Straub, 2009).

The focus of the present work is on studying the emotional status of a learning process when different teaching methods are applied. This concept has been used previously by Sánchez-Martín et al. (2017a,b), and namely is considered to be the emotional yield of a learning process. Obviously, it is linked to the academic success, if one thinks this success is not only the immediate result, but the benefit (regarding the knowledge and the attitudes) that is obtained in the long-term. The academic content, as well as the time spent at class, should be intrinsically considered as a good time, a pleasant one, only in the case positive emotions arise during the process itself. And this is a teacher's task. Negative emotions will probably drive on the other direction. This is the reason that care with the emotions in learning is not only advisable for immediate academic success, but also for maintaining a good mental attitude with which to face possible cases of temporary failure in the future with the need to make another attempt.

But how is one to measure emotions? This is an important scientific question as many authors have suggested a broad variety of ways to measure these variables. Mauss and Robinson (2009) published a full review where five response systems were identified, although many of them involved the use of physical instruments (such has EEG) for measuring it. In general, most of them are inapplicable to a teaching and learning environment, and almost none can be applied systematically as we need.

Pekrun, Vogl, Muis and Sinatra (2016) recently presented an interesting questionnaire to measure emotions in epistemic and science activities. We concur with their observation that measurement instruments with which to assess multiple emotions during epistemic activities are largely lacking (Pekrun et al., 2016: page 1). But 
there is still difficulty in measuring emotions since that questionnaire catalogues seven emotions (surprise, curiosity, enjoyment, confusion, anxiety, frustration, and boredom), making it difficult to implement any systematic measurement with acceptable accuracy. In this sense, it is also worth noting the effort made by Yuen, San, Rizon and Seong (2009) to simplify the measurable taxonomy of emotions to just five types, including a neutral classification.

These results and, since we are interested in how such feelings evolve and their relationship with different teaching methods, our need for a systematic method of measuring emotions led us to elaborate a new, simple, taxonomy of emotions. This taxonomy is based on the positive/negative catalogue of Brígido, Couso et al. (2013). We adopted a model that classifies the possibilities on two axes: positive-negative and dynamic-static. (This simple taxonomy is represented in Figure 1 and will be explained in Section 2.1.)

The main objective of the present study was to identify the relationship between different teaching methods and the students' emotional performance when they are faced with them. Since we wished to analyse the emotional responses in a systematic way, the consistency and coherence of the results should be greater than if questions were put only twice or thrice during the course. Given this perspective of continuous measurement of the emotions, this research was based on the following two questions:

Does the teaching method actually affect the students' emotional responses when they are dealing with science?

If so, do innovative methodological approaches arouse more positive emotions than traditional approaches?

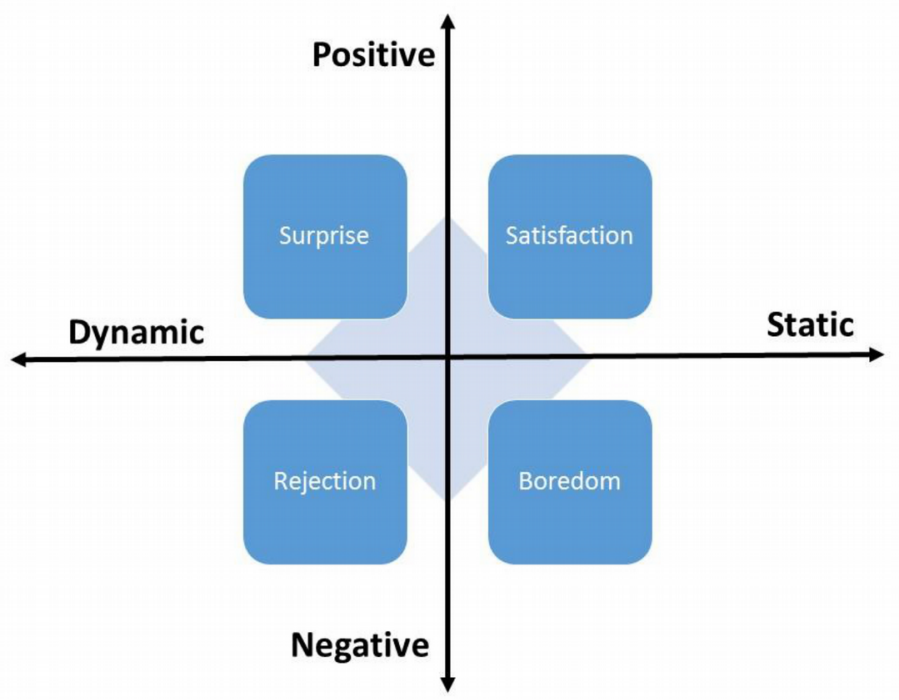

Figure 1. The taxonomy of emotions that was used in this work

\section{Methods}

The study was conducted with 120 students - 47 men and 73 women - who were prospective primary teachers in their last (4th) undergraduate year, taking the subject "Knowledge of the Natural Environment in Primary Education". They were systematically asked to select the prevalent emotion they felt during the class from among 4 options, resulting in 17 measurements of emotions for each participant taken from September to December. Data acquisition was through the Web application Plickers ${ }^{\mathrm{TM}}$. This allows each student to select an option by holding a card up in the air in a very fast process at the end of each class. The final data were processed with the SPSS statistical program package (SPSS, 2005). The significance level was taken to be $\alpha=0.05$ (i.e., 95\% confidence). The quantity and immediacy of the data relative to 
the traditional questionnaire method might be the present study's main contribution to knowledge of the emotions in teaching and learning.

\subsection{The Emotions}

As noted above, we adopted a two-axis classification of emotions. Figure 1 shows this taxonomy graphically. As one observes, we split the possibilities into four options which were appropriately explained to the students prior to each choice. These options were the following:

1. Rejection, an emotion corresponding to the dynamic and negative quadrant. The explanation given to the students is that rejection means wanting to be far away from the class, feeling some kind of anxiety, and a complete refusal of the subject. With this option, we try to cover the worst feelings, the most negative emotions.

2. Surprise is the opposite in our taxonomy. It implies positive and pro-active attitudes towards the subject. Students who feel surprise find good feelings arising, and probably want more from the teacher because they like what they are learning.

3. Boredom is the traditional negative emotion in the static region of our taxonomy. It is thought of as a non-motivating emotion that arises when the student thinks the subject is uninteresting, although harmless. I.e., it is OK, but I would rather be doing something else.

4. Satisfaction, the last emotion, is the positive feeling of being $\mathrm{OK}$, but not wanting any more. It implies a static position. It is the traditional location of the spectator. Minimal motivation is needed, just enough to follow the explanation or the teaching method, but without any personal involvement being required.

As can be seen, it is quite easy to isolate one prevalent emotion in each class. The students were aware of the different implications of these emotions (most of them could be further split into other emotions), but no doubts were recorded when they were deciding on which feeling to select for each class.

\subsection{Teaching Methods}

During the course, five methods of teaching were followed which the students were usually able to identify:

1. Pure Oral Presentation: The traditional one-way transmissive presentation, although we usually include some $20 \%$ of student participation in the form of dialogue, hook questions, etc.

2. Oral Presentation plus Gamification: A relevant and significant gamification event is included in a traditional oral presentation context. This might be a Kahoot! ${ }^{\mathrm{TM}}$ contest or something similar.

3. Oral Presentation with Audiovisual Resources: This time, the oral presentation is accompanied by a video that supports the explanations. This video may comprise clips of commercial films or Internet videos.

4. Oriented Research: A guided inquiry activity to acquire some scientific knowledge. This method is sometimes termed inquiry-based learning. We have adopted this different name because autonomous research, although guided by the teacher, was prevalent rather than the question itself. The students worked in teams to take up a complex problem based on some scientific topic. The teacher only facilitated the acquisition of knowledge.

5. Hands-On Activities: Traditional laboratory work with a prior explanation. The students worked in teams to actually carry out the experiments with their own hands.

As can be seen, the pure oral presentation is linked with the traditional one-way transmission educational paradigm, while the other strategies can readily be assigned to more innovative methodological approaches. 
The working subject was entitled "Knowledge of the Natural Environment in Primary Education". It is focused on teaching both didactic strategies and the content knowledge of natural science. For this reason, each of the five teaching methods was applied to a specific part of the subject (a summary of this division is given in Table 1).

Finally, the students were asked to identify the main reason for feeling the prevalent emotions, choosing from personal disposition, teaching methodology, the subject being taught, or other reasons.

\begin{tabular}{|c|c|c|c|}
\hline Teaching method & Science content & Didactic content & $\begin{array}{c}\mathbf{N}^{\circ} \text { of } \\
\text { sessions }\end{array}$ \\
\hline Pure oral presentation & Contextual reference & $\begin{array}{l}\text { Misconceptions and naïve ideas } \\
\text { in science education } \\
\text { Constructivism in science } \\
\text { teaching }\end{array}$ & 6 \\
\hline Gamification & Phase changes of matter & $\begin{array}{c}\text { Significant learning } \\
\text { Misconceptions and naïve ideas } \\
\text { in science education }\end{array}$ & 3 \\
\hline $\begin{array}{l}\text { Audiovisual-supported } \\
\text { presentation }\end{array}$ & Contextual reference & $\begin{array}{l}\text { Oral presentation, verbal } \\
\text { learning and master class in } \\
\text { science teaching }\end{array}$ & 2 \\
\hline Hands-on activities & $\begin{array}{l}\text { Phase changes of matter } \\
\text { Basic thermology, heat transfer } \\
\text { Solubility, colligative properties } \\
\text { Density, buoyancy, Archimedes' principle }\end{array}$ & $\begin{array}{l}\text { Designing laboratory activities } \\
\text { for primary education } \\
\text { The laboratory notebook for } \\
\text { primary students }\end{array}$ & 3 \\
\hline Oriented research & $\begin{array}{c}\text { Phase changes of matter } \\
\text { Basic thermology, heat transfer }\end{array}$ & $\begin{array}{l}\text { Didactic application of } \\
\text { problem solving }\end{array}$ & 3 \\
\hline
\end{tabular}

Table 1. Distribution of the content in each teaching method

\section{Results and Discussion}

\subsection{Qualitative Description of the Sample}

Apart from the large number of students this work dealt with, the fact that they were prospective primary teachers in a Faculty of Education (rather than one of Science or similar) makes this sample relatively different from others. The general profile of a standard student in this course merits a specific description that is based not only on quantitative data, but also, and above all, on personal and direct observation:

a) As Jeong et al. (2016) recently pointed out, the academic background of students in this degree course is mainly linked to social science or arts studies. Moreover, they do not identify their studies aimed at becoming a primary education teacher as being science, and obviously they do not think that much science content needs to be known to be a good primary school teacher.

a) As a consequence of the previous item, those values traditionally linked to a scientific education (curiosity, observation, surprise, etc.) are not present by default in the present sample of students. Even more so, the initial emotions that this kind of student has towards questions of science are closer to rejection than personal interest (Dávila-Acedo, Borrachero-Cortés, Cañada-Cañada, Martínez-Borreguero \& Sánchez-Martín, 2015).

b) The academic structure of the Primary Teaching Bachelor's course covers a huge number of different materials, belonging to a large variety of academic fields (arts, literature, physical education, music, history, geography, science among others). This has a direct influence on the importance and relevance the students give to each of these materials. We find that, since science education is not an interesting subject for the students doing this degree, it is put in last place in order of importance. 
c) One result of these circumstances is that the students pass their science education subjects with relatively low marks (González-Gómez, Jeong, Airado-Rodríguez \& Cañada-Cañada, 2016).

\subsection{Data Reliability and Differences between Teaching Methods}

The data set consisted of almost 800 emotional measurements, collected from 120 students during the first semester of the 2016/2017 course. The first aspect to confirm was the reliability of the responses. As indicated above, after each class the students were asked to select one of the four possible emotions. These emotions were appropriately explained, and each student was asked to choose which was the most prevalent according to their feelings during the class. In an initial step, the reliability of the results should be checked from the avoidance of any kind of default response, i.e., individuals who always (or suspiciously often) gave the same response. Since our data are qualitative, a $\chi^{2}$ test is the statistic best suited to them. This measures the relevance of the dependence among two or more qualitative variables (Taylor, 2005), and the significance can be given by the p-value of the test itself, the correlation factor, Cramer's V, or the phi-value.

The reliability of the data set in avoiding default responses was adequately confirmed by the corresponding $\chi^{2}$ test, checking the variable Individual and the variable Main Emotion. Note that, with the application of the Plickers ${ }^{\mathrm{TM}}$ method, each participant gave their response immediately after the class, for which reason we were able to treat a large number of emotional measurements. The $\chi^{2}$ test applied to the variables Individual (the case number) and Main Emotion (the response) was not significant ( $\mathrm{p}$-value greater than 0.05 ) in Pearson's correlation test and Cramer's V test. This means that no default response was observed - the sample were giving responses that did not depend on any external or non-academic pattern.

The $\chi^{2}$ test was subsequently applied to identify which teaching practices were linked to better emotional responses. In other words, we aimed to find an answer to the following question:

Are there significant differences in terms of emotional performance between these five teaching methods in a General Science classroom?

The statistical significance was confirmed (Table 2), i.e., the numerical data confirmed the relationship between the kind of teaching method and the main emotional response. The four statistical tests that were applied $-\chi^{2}$, phi, Cramer's V, and the contingency coefficient - all clearly presented significant p-values, although the correlation was not strictly applicable given the qualitative nature of the data (Colardaci, 2013).

Once the relationship between the two categories had been established, it was necessary to evaluate how these teaching methods affect the emotional performance. Table 3 presents the $\chi^{2}$ test data in terms of the percentages at which each emotion appears with each teaching method. One observes that there are extreme values for the dynamic emotions in innovative methods such as Hands-on activities (greatest values of rejection, 5.7\%, and of surprise, 51.4\%). Oriented research also accounted for the second place in rejection $(5.2 \%)$, whereas the traditional Oral presentations (with or without audiovisual support) were the methods that led to more static emotions: the students reported $25 \%$ and $14.5 \%$ of boredom, and $75 \%$ and $62.2 \%$ of satisfaction, for the Audiovisual-supported presentation and the Pure oral presentation, both respectively. These were statistically significant data, not just mere descriptive statistics of the experience. It was also notable that there was no temporal evolution of the emotions for this kind of teaching method, i.e., the Pure oral presentation classes presented similar frequencies of the emotions right from the beginning of the semester.

\begin{tabular}{|l|r|}
\hline Number of participants & 120 \\
\hline Number of emotion measurements & 784 \\
\hline Pearson's $\chi^{2}$ & 99.8 \\
\hline $\begin{array}{l}\text { Significance level for Pearson's } \chi^{2}, \text { phi, Cramer's V, } \\
\text { and the contingency coefficient }\end{array}$ & 0.00 \\
\hline
\end{tabular}

Table 2. Test statistics and significance level 
In view of the results presented in Table 3, it is clear that one can make three statements: (1) there exist significant differences in the students' emotional responses when facing different teaching methods; (2) Hands-on activities and Gamification are the methods that lead to most surprise, whereas Audiovisual support does not represent any innovation for the students (moreover, they find it to be the most boring method); and (3) Oriented research is far from being an advisable method with which to try to engage the students they seem to prefer Gamification and Hands-on activities. The initial explanation for these findings may be that, as was mentioned above, these students are not used to doing practical laboratory activities or to seeing science as something that is fun. Despite these statistics however, it is difficult to draw any clear conclusions from Table 3.

\begin{tabular}{|l|r|r|r|r|}
\hline \multicolumn{1}{|c|}{ Method } & \multicolumn{1}{c|}{ Rejection } & Boredom & Satisfaction & \multicolumn{1}{c|}{ Surprise } \\
\hline Oral presentation with audiovisual support & $0 \%$ & $25 \%$ & $75 \%$ & $0 \%$ \\
\hline Oriented research & $5.2 \%$ & $23.6 \%$ & $52.4 \%$ & $18.8 \%$ \\
\hline Pure oral presentation & $0.3 \%$ & $14.5 \%$ & $62.2 \%$ & $23 \%$ \\
\hline Oral presentation plus gamification & $1.3 \%$ & $7.5 \%$ & $48.1 \%$ & $43.1 \%$ \\
\hline Hands-on activities & $5.7 \%$ & $6.7 \%$ & $36.2 \%$ & $51.4 \%$ \\
\hline
\end{tabular}

Table 3. The $\chi^{2}$ test data for Teaching Method vs Main Emotion

\subsection{Positive and Dynamic Emotions and their Relationship with the Teaching Method}

To go in greater depth into the results, one might wonder whether or not the taxonomy applied is useful for the analysis of the data. To this end, the data set was re-arranged to count the number of (a) positive and negative and (b) static and dynamic emotions experienced by each participant for each method. The frequency counts convert our qualitative data set to a quantitative one. The data were then subjected to a new analysis in the form of two one-way ANOVAs in order to respond to the following question:

Since our taxonomy involves classiffing the emotions into two categories (positive vs negative, and static vs dynamic), is either of them mainly assignable to one or more of the teaching methods?

We performed two statistical tests to determine whether the emotional prevalence (in accordance with the aforementioned taxonomy) is linked to the teaching methods that were studied. The first ANOVA test opposed Method and Positive emotional responses, and the second opposed Method and Dynamic emotional responses. The results of these analyses are presented in Table 4 . The significance of the tests is confirmed by the low p-values ( 0.00 in both cases) and by the F-factors. The results confirmed that both the positive emotions and the dynamic emotions are related to the teaching method applied. In the first case, this dependence can be summarized by the fact that Oriented research is significantly different (with a lower score) from the rest of the methods studied in terms of the positive emotions reported, i.e., the students indicated that they less often felt positive emotions (or more often negative ones) when an Oriented research teaching method was used. The other strategies were indistinguishable from each other - the students referred to the same level of positive emotions.

Graphically, a post-hoc test can be applied (Tukey's honest significant difference or HSD test) in order to distinguish groups of similar scores. In this sense, Figure 2 plots the estimated marginal means in frequency counts of positive emotions. As it clearly shows, the Oriented research method reached a level (between 0.70 and 0.75 ) that was significantly lower than the rest.

\begin{tabular}{|l|r|r|}
\hline \multicolumn{1}{|c|}{ Dependent variable } & \multicolumn{1}{c|}{ F-value } & \multicolumn{1}{c|}{ p-value } \\
\hline Positive emotional response & 7.83 & 0.00 \\
\hline Dynamic emotional response & 18.91 & 0.00 \\
\hline
\end{tabular}

Table 4. One-way ANOVA tests for Teaching Method vs Emotional Responses categorized in terms of the applied taxonomy of emotions 


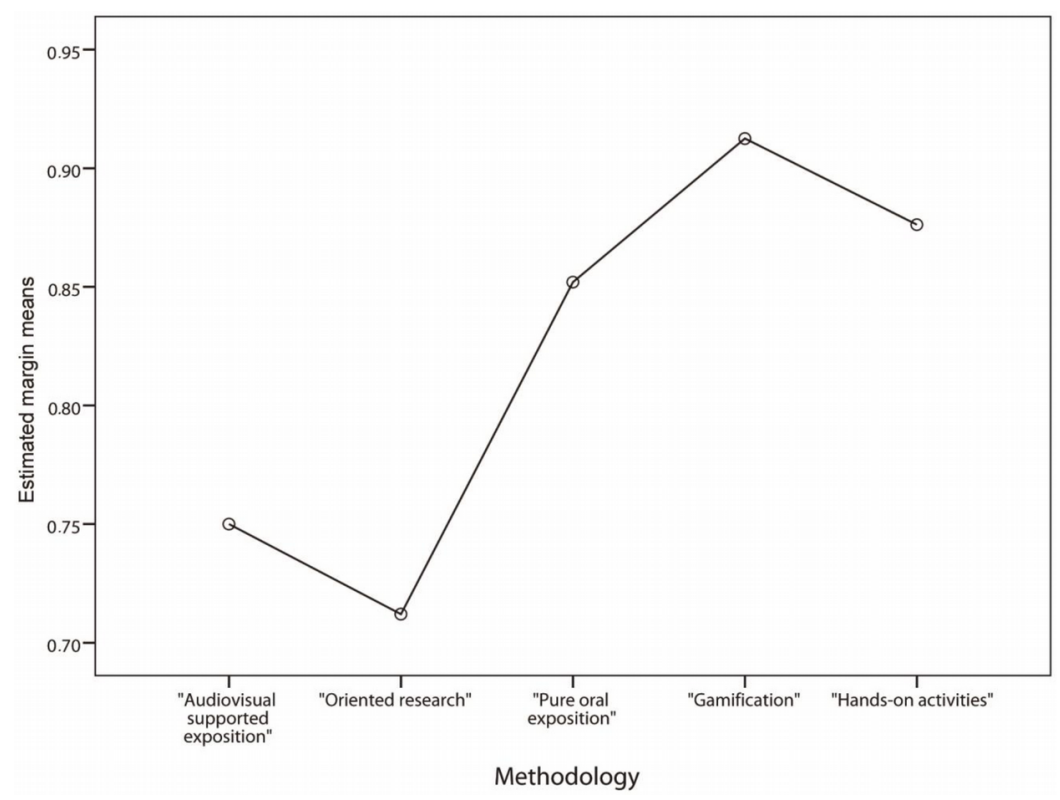

Figure 2. Estimated marginal means for Positive Emotions vs Teaching Method

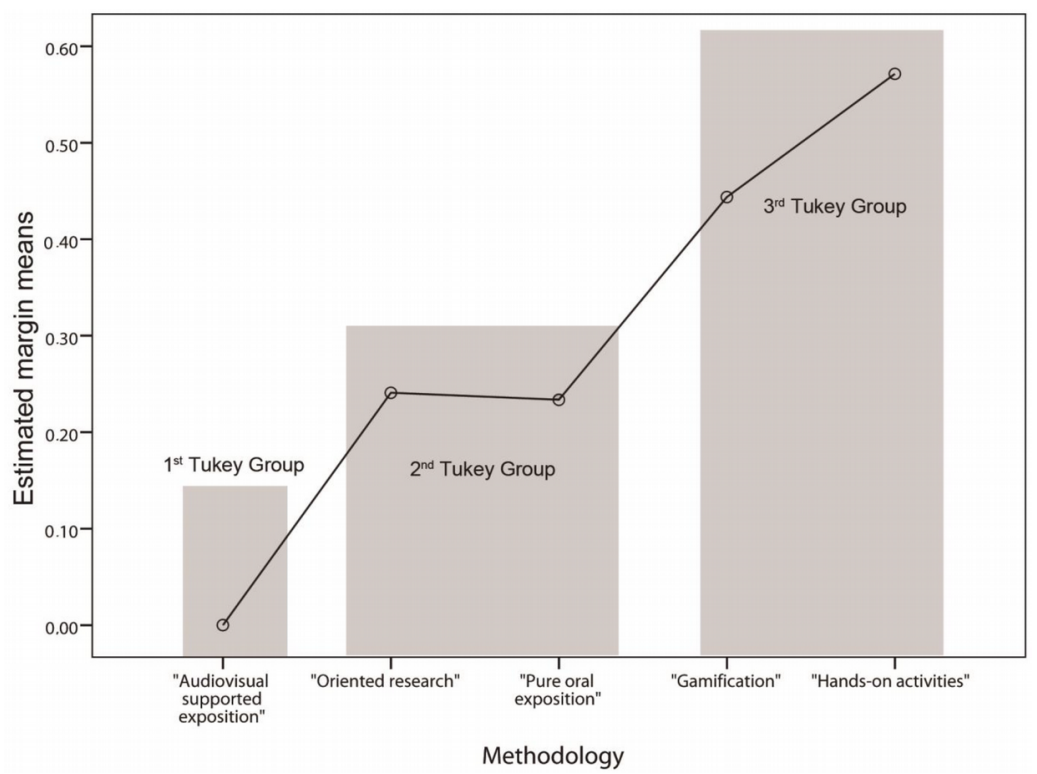

Figure 3. Estimated marginal means for Dynamic Emotions vs Teaching Method

But perhaps the most interesting insight from the use of this emotion taxonomy is the fact that dynamic emotions clearly divided the teaching methods into three Tukey groups: Gamification and Hands-on activities; Oriented research and Pure oral presentation; and Audiovisual-supported presentation. In particular, the methods which most actively affected the students (either positively with the emotion of surprise, or negatively with the emotion of rejection) were those with most participation, while, complementarily, the greatest level of static emotions corresponded to the Audiovisual-supported presentation. This is shown graphically in Figure 3.

The preliminary results could suggest a tendency in the students' emotional responses to the different teaching methods: it seems that dynamic emotions are favoured by those methods which clearly involve the students in the teaching and learning process, whether with direct manipulation (Hands-on activities) or through play (Gamification). This is concordant with previous ideas, such as that expressed by Fried (2001: page 199): 
Giving students real jobs to do begins when teachers help students discover the link between classroom learning and issues, challenges, and projects of importance to people outside the world of school.

And, in the same line of argument, again Fried (2001: page 125) states that:

A spectator is a student who sits while the teacher or another student performs. A spectator is passive, able to drift off or daydream while the teacher gives his or her version of what the learning task is about. By contrast, a player is engaged at the start with a clearly active role in the discovery of knowledge. Once in the game, players naturally want to keep playing.

\subsection{Reasons for the Students' Emotional Responses}

Although the results are quite clear in segregating the methods in terms of the different emotions that they arouse, the direct question put to the students

\section{What is the reason for your feeling the prevalent emotion that you selected in each class?}

may give us an even more explicit picture of what were the main reasons for the emotions that were reported. The results are presented in Figure 4.

As can readily be seen, the prevalent reason for the emotions reported was the teaching methodology, i.e., almost half of the students (44\%) identified this factor as the main variable affecting their feeling surprise, rejection, boredom, or satisfaction. The second reason for their emotional response was the subject or the nature of the content $(36 \%)$. It is more than evident that numerical, arithmetic, or mathematical content (in a broad sense of the term) usually cause negative emotions to arise. This is the case with the Oriented research method which was applied mainly to phase changes in matter and basic thermology (Table 1). The difference from Hands-on activities is the fact that, in the laboratory, the students are not asked to solve problems mathematically (i.e., they do not use calculations, but simply carry out the activities and experiments instead). This could be the reason that the Oriented research method reached such a low emotional performance and would be consistent with previous findings in the literature, such as those recently reported by Towers, Takeuchi, Hall and Martin (2017).

The rest of the reasons together only account for $18 \%$ of the responses, which makes the personal attitude of mind of just a residual origin for the emotional response.

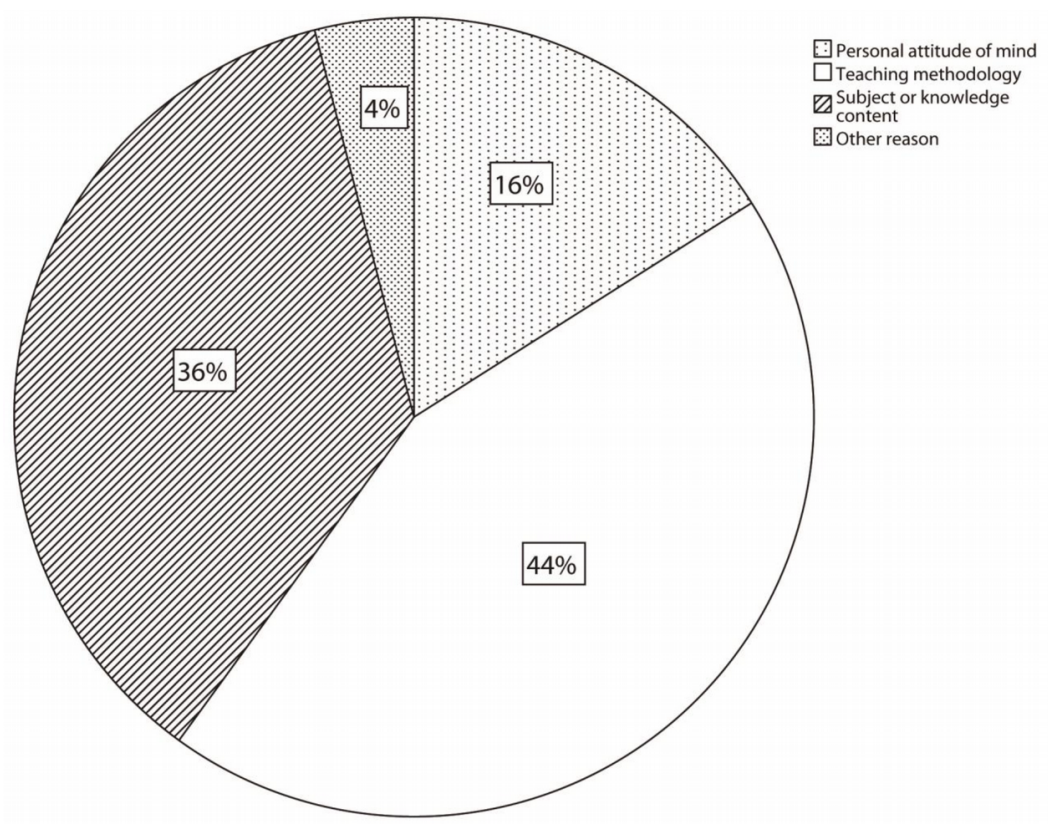

Figure 4. Reasons the students gave for choosing the prevalent emotion after each class 


\section{Conclusions}

This study has described a continuous measurement of emotions in 120 undergraduate prospective primary teachers. Each one reported their prevalent emotion following a General Science class up to 17 times. This gave us a large number of measurements with which to examine the tendency of their emotional performance with different teaching methods. The method that achieved the greatest frequency of surprise was Hands-on activities (traditional laboratory tasks), while Audiovisual-supported oral presentation was the most boring teaching method.

The four teaching methods studied in the current work presented statistically significant differences in terms of emotional performance. Those which engaged the students by getting them to participate (Hands-on activities and Gamification) presented the highest levels of dynamic emotions, while the Oral presentations and Oriented research did not arouse these emotions (especially surprise).

Lastly, the students clearly identified the teaching method as being the main reason for feeling their prevalent emotion. Consequently, those methods which achieve the students' greater engagement should be favoured and promoted, since they significantly improve the students' emotional responses.

\section{Declaration of Conflicting Interests}

The authors declared no potential conflicts of interest with respect to the research, authorship, and/or publication of this article.

\section{Funding}

This work was financed by Research Project EDU2016-77007-R (AEI/FEDER, UE) of Spain's Ministry of Economy and Competitiveness, and by Research Project IB16068 of the Regional Government of Extremadura, partially funded by the European Regional Development Fund.

\section{References}

Bisquerra, R. (2001). Emotional education and welfare (Educación emocional y bienestar). Barcelona: Wolters, Kluwer.

Bisquerra, R. (2009). Psychopadagogy of the emotions (Psicopedagogía de las emociones). Madrid: Síntesis.

Black, P., \& Atkin, M. (2005). Changing the subject: Innovation in Science, Mathematics and Technology Education. London, OECD.

Borrachero, A.B., Brígido, M., Gómez, R., Bermejo, M.L., \& Mellado, V. (2011). Emotions in prospective secondary teachers on the science learning and teaching process (Las emociones de los futuros profesores de secundaria sobre el aprendizaje y la enseñanza de las ciencias). International Journal Of Developmental and Educational Psychology, 23(2), 521-530.

Borrachero, A.B., Brígido, M., Mellado, L., Costillo, E., \& Mellado, V., (2014). Emotions in prospective secondary teachers when teaching science content, distinguishing by gender. Research in Science and Technological Education, 32(2), 182-215. https://doi.org/10.1080/02635143.2014.909800

Brígido, M., Borrachero, A., Bermejo, M.L., \& Mellado, V. (2013). Prospective primary teachers' self-efficacy and emotions in science teaching. European journal of teacher education, 36(2), 200-217. https://doi.org/10.1080/02619768.2012.686993

Brígido, M., Couso, D., Gutiérrez, C., \& Mellado, V. (2013). The emotions about teaching and learning science: a study of prospective primary teachers in three Spanish universites. Journal of Baltic Science Education, 12(3), 299-311.

Casacuberta, D. (2000). What is an emotion? Barcelona: Crítica. 
Colardaci, T. (2013). Fundamentals on statistical reasoning in education (22nd ed.). Wiley.

Damasio, A. (1996). Descarte's mistake (El error de Descartes). Barcelona: Crítica.

Damasio, A. (2010). And the brain created man (Y el cerebro creó al hombre). Barcelona, Destino.

Dávila-Acedo, M.A., Cañada-Cañada, F., Sánchez-Martín, J., \& Mellado V. (2016). Emotions in learning Physics and Chemistry in secondary education. Students related causes. Educación Quimica, 27(3), 217-225.

Dávila-Acedo, M.A., Borrachero-Cortés, A.B., Cañada-Cañada, F., Martínez-Borreguero, M.G., \& SánchezMartín, J. (2015). Evolution of the emotions experienced by prospective Primary teachers, focused on Didactics of Matter and Energy. Eureka Journal of Science Education and Divulgation, 12(3), 550-564.

Dos Santos, F.M.T., \& Mortimer, E.F. (2003). How emotions shape the relationship between a chemistry teacher and her high school students. International Journal of Science Education, 25(9), 1095-1110. https://doi.org/10.1080/0950069032000052216

Duit, R., Treagust, D.F., \& Widodo, A. (2008). Teaching science for conceptual change: theory and practice. In Vosniadou, S. (Ed.), International handbook of research on conceptual change (629-646). New York, Routledge.

FECYT (2014). VII Survey on Science Social Perception. Technical report. Ministry of Economy and Competitivity. Spanish Government.

Fernández-Abascal, E., Martín, M., \& Domínguez, J. (2001). Psychological processes (Procesos psicológicos). Madrid: Pirámide.

Francisco, V., Gervás, P., \& Hervás, R. (2005). Analysis and synthesis of the emotional expression in read-aloud tales (Análisis y sintesis de expresión emocional en cuentos leídos en voz alta). Natural language process (Procesamiento del lenguaje natural), 35, 293-300.

Fried, R.L. (2001). The passionate teacher. A practical guide. Boston, Massachusetts: Beacon Press.

Goleman, D. (1996). Emotional intelligence. New York: Bantam Books.

González-Gómez, D., Jeong, J.S., Airado-Rodríguez, D., \& Cañada-Cañada, F. (2016). Performance and Perception in the Flipped Learning Model: An Initial Approach to Evaluate the effectiveness of a New Teaching Methodology in a General Science Classroom. Journal of Science Education and Technology, 25(3), 450-459. https:// doi.org/10.1007/s10956-016-9605-9

Hargreaves, A. (1998). The emotions of teaching and educational change. In Hargreaves, A., Lieberman, M., Fullan, M., \& Hopkins, D. (Eds.), International handbook of educational change (558-575). Dordrecht/Boston/London: Kluwer Academic Publishers. https://doi.org/10.1007/978-94-011-4944-0_28

Jeong, J.S., González-Gómez, D., \& Cañada-Cañada, F. (2016). Students’ Perceptions and Emotions Toward Learning in a Flipped General Science Classroom. Journal of Science Education and Technology, 25(5), 747-758. https://doi.org/10.1007/s10956-016-9630-8

Lavonen, J., Gedrovics, J., Byman, R., Meisalo, V., Juuti, K., \& Uitto, A. (2008). Students' motivational orientations and career choice in science and technology: a comparative investigation in Finlad and Latvia. Journal of Baltic Science Education, 7(2), 86-102.

Manassero, M. (2013). Emotions: from omission to relevancy in the behavior explanation (Emociones: del olvido a la centralidad en la explicación del comportamiento). In Mellado, V., Blanco, L.J., Borrachero, A.B., \& Árdenas, J.C. (Eds.), Emotions in the Science and Mathematics teaching and learning process (Las emociones en la enseñanza y el aprendizaje de las ciencias y las matemáticas) (2) (3-18). DEPROFE. 
Marbá-Tallada, A., \& Márquez, C. (2010). What do students think of Science lessons? A transversal study from the sixth year of primary to the fourth of lower secondary education (¿Qué opinan los estudiantes de las clases de ciencias? Un estudio transversal de sexto de primaria a cuarto de ESO). Enseñanza de las ciencias, 28(1), $19-30$.

Mauss, I.R., \& Robinson, M.D. (2009). Measures of emotion: a review. Cognition and Emotion, 23(2), 209-237. https://doi.org/10.1080/02699930802204677

Mellado, V., Borrachero, A.B., Brígido, M., Melo, L.V., Dávila, M.A., Cañada, F. et al. (2014). Emotions in Science teaching. Enseñanza de las Ciencias, 32(3), 11-36.

Mooney, M.A., \& Laubach, T.A. (2002). Adventure Engineering: A Design Centered, Inquiry Based Approach to Middle Grade Science and Mathematics Education. Journal of Engineering Education, 91(3), 309-318. https:// doi.org/10.1002/j.2168-9830.2002.tb00708.x

Otero, M.R. (2006). Emotions, feelings, and reasoning in science education (Emociones, sentimientos $y$ razonamientos en didáctica de las ciencias). Electronic Journal of Science Education (Revista electrónica en educación en ciencias), 1(1).

Pekrun, R., Vogl, E., Muis, K.R., \& Sinatra, G.M. (2016).Measuring emotions during epistemic activities: the Epistemically-Related Emotion Scales. Cognition and Emotion, 22(0), 1-9.

Pintrich, P.R., Marx, R.W., \& Boyle, R.A. (1993). Beyond cold conceptual change: the role of motivational beliefs and classroom contextual factors in the process of conceptual change. Review of Educational Research, 63(2), 167-199. https://doi.org/10.3102/00346543063002167

Rocard, M., Csermely, P., Jorde, D., Lenzen, D., Walberg-Henriksson, H., \& Hemmo, V. (2007). Science Education Now: a renewed pedagogy for the future of Europe. Belgium: European Communities.

Sánchez-Martín, J., Álvarez-Gragera, G.J., Dávila-Acedo, M.A., \& Mellado, V. (2017a). What do K-12 students feel when dealing with technology and engineering issues? Gardner's multiple intelligence theory implications in technology lessons for motivating engineering vocations at Spanish Secondary School. European Journal of Engineering Education, 42(6), 1330-1343.

https://doi.org/10.1080/03043797.2017.1292216

Sánchez-Martín, J., Álvarez-Gragera, G.J., Dávila-Acedo, M.A., \& Mellado, V. (2017b). Teaching techonology: From knowing to feeling. Enhancing emotional and content acquisition performance through Gardner's Multiple Intelligences Theory in Technology and Design lessons. Journal of Technology and Science Education, 7(1). https://doi.org/10.3926/jotse.238

SPSS (2005). SPSS 14.0 Developer's guide. Chicago, Illinois: IBM.

Straub, E.T. (2009). Understanding technology adoption: Theory and future directions for informal learning. Review of Educational Research, 79(2), 625-649. https://doi.org/10.3102/0034654308325896

Taylor, G.R. (2005). Integrating quantitative and qualitative methods in research (2 ${ }^{\text {nd }}$ ed.). University Press of America.

Thagard, P. (2009). Why Cognitive Science Needs Philosophy and Vice Versa. Topics in Cognitive Science, 1(2), 237-254. https://doi.org/10.1111/j.1756-8765.2009.01016.x

Towers, J. Takeuchi, M.A., Hall, J., \& Martin, L.C. (2017). Students' emotional experiences learning mathematics in Canadian schools. In Xolocotzin, $\mathrm{U}$ (Ed.), Understanding emotions in mathematical thinking and learning. Academic Press. https://doi.org/10.1016/B978-0-12-802218-4.00006-6 
Vázquez, A., \& Manassero, M.A. (2007). In defence of attitudes and emotions in science education (I): Evidence and general arguments (En defensa de las actitudes y emociones en la educación cientifica (I): Evidenciasy argumentos generales). Eureka Journal of Science Education and Divulgation (Revista Eureka sobre Enseñanza y Divulgación de las Ciencias), 4(2), 247-271.

Vázquez, A., \& Manassero, M.A. (2011). The decline in children's attitudes towards science in compulsory education (El descenso de las actitudes hacia la ciencia de chicos y chicas en la educación obligatoria). Ciência e Educacaşâo, 17(2), 249-268.

Weiner, B. (1986). An attributional theory of motivation and emotions. New York: Springer. https://doi.org/10.1007/978-1-4612-4948-1

Wu, H.K., \& Huang, Y.L. (2007). Ninth-grade student engagement in teacher-centered and student-centered technology-enhanced learning environment. Science Education, 91(5), 727-749. https://doi.org/10.1002/sce.20216

Yuen, T.C., San, W.S., Rizon, M., \& Seong, T.C. (2009). Classiffication of human emotions from EEG signals using statistical features and neural network. International Journal of Integrated Engineering (Issue on Electrical and Electronic Engineering), 1(3), 71-79.

\section{Published by OmniaScience (www.omniascience.com)}

Journal of Technology and Science Education, 2018 (www.jotse.org)

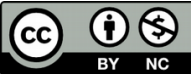

Article's contents are provided on an Attribution-Non Commercial 4.0 Creative commons International License.

Readers are allowed to copy, distribute and communicate article's contents, provided the author's and JOTSE

journal's names are included. It must not be used for commercial purposes. To see the complete licence contents, please visit https://creativecommons.org/licenses/by-nc/4.0/. 